\title{
Attitudinal Changes Due to Unanticipated Transition to Remote Work
}

\author{
Dr. Jeyalakshmi $\mathrm{R}^{1 *}$, Dr. S.Sivarajeswari ${ }^{2}$, Dr.V.Selvalakshmi ${ }^{3}$ \\ ${ }^{1}$ Assistant Professor, Department of Management Studies, Sri Sairam Engineering College, Chennai, India \\ ${ }^{2}$ Assistant Professor, Department of Electrical \& Electronics Engineering, Sri Sairam Institute of Technology, \\ Chennai, India \\ ${ }^{3}$ Assistant Professor, Department of Management Studies, SRM Valliammai Engineering College, Chennai, \\ India \\ jeyalakshmi.mba@gmail.com
}

\begin{abstract}
Human Resource management is a herculean task during the world-wide lock down due to the pandemic covid19. Remote work, though having its own merits, may not be suitable to everyone. This study is aimed at identifying the major factors influencing work from home. This study is also aimed at analysing the relationship between the independent factors well being, disturbance factor and stressors and the dependent factor job satisfaction at work from home. This study is carried out with respondents from IT/ITES sector in Chennai who do work from home due to this pandemic lockdown through a structured questionnaire. The study uses principal component analysis to identify the major factors such as wellbeing, disturbance factors, stressors and job satisfaction. This study also uses ordinal regression to find the relationship between the factors. The findings revealed that job satisfaction during remote work is affected by well being of the employees, disturbance factors at work while working from home and stress factors due to the sudden adoption of remote work.
\end{abstract}

Keywords: Remote work, work from home, job satisfaction, factor analysis, ordinal regression

\section{INTRODUCTION}

The pandemic covid-19 has created an intense impact throughout the world. India being affected by this covid-19 declared the outbreak as pandemic and then announced a 21-day lockdown nationwide starting from March 24, 2020. (1. Tolbert \& Simons, 1994,) Companies worldwide adopted work from home to limit the disruptions in production. Many companies allowed their office to work from home even before the official announcement of lockdown to ensure the safety of employees and also to prevent the social spread of viruses. Besides the IT companies, manufacturing firms and some service providers also provided work from home for their employees. Hindustan Unilever, the major manufacturing brand in India and Indigo, the airline service company are witnessed to be among the first to adopt the remote work option for their office employees (Brett Williams, 2010). This situation has created a psychological impact on every citizen. Though work from home is not new to Indian IT employees, many are not used to remote work. Employees are not prepared enough for remote work.
It is stated that working at home adversely affects the career growth of employees as the supervisors are inclined to negatively impact the employee's performance (Berinato et al., 2014,). Remote work may result in personal implications such as lack of self esteem, loneliness, isolation and motivation (Tracey Crosbie \& Jeanne Moore, 2004). This study is classified into four segments such as understanding the lifestyle changes and work style changes happened in work from home during the lockdown, measuring the level of job satisfaction among employees at work from home, to identify the impact of various demographic factors on job satisfaction and relationship between lifestyle and job satisfaction.

\subsection{India and Covid-19}

The World Health Organisation reported that Covid-19 was detected as pneumonia caused by unknown sources and it is detected in Wuhan, China. WHO declared the outbreak as an urgent situation concerning international public health [WHO, 2020]. Covid19 reaches other people when they are in 
contact with the infected while they sneeze or cough. The first case in India was reported with three students in Kerala who returned from the affected Wuhan city. The spread escalated in the month of March as many travellers had been infected with the disease. To prevent the social spreading, the government decided to go for a nation-wide lockdown to stop social spreading from March 24, 2020 [Hernan Dario, 2020]. Except the essential services all the other commercial, religious, industrial and cultural activities were shut down. The flight services, train services and even bus services got stopped. This affected many people but some companies opted for the remote work to prevent them.

\subsection{Remote work}

Remote work which is commonly called as work from home is not a new practice. It gives advantage for both employers and employees. Remote work is increasing in developing countries like the US [Prithwiraj(Raj) Choudhury, 2019]. Many companies, especially IT firms, are used to working from home. During summer in 2019, many companies opted for work from home due to water scarcity. This covid-19 also created a need for work from home. Employees consider work from home provides a balance between work and life [Donna Harrington, 2009]. The productivity level of people gets increased and half of the people doing remote work are staying with the company [WHO, 2020]. It is said that job related factors, work style characteristics and household factors have some kind of influence in work from home [Madhumitha Jaganmohan, 2020].

\section{3, Variables Under Study}

\subsubsection{Job Satisfaction}

Job satisfaction is often confused with motivation (Mullins, 2005). Job satisfaction is defined as the combination of psychological, physiological and situational based one that makes any employee admit that he is content with his job (Happock, 1935). Employee satisfaction can be improved if they are provided with a proper working condition. (Naga Bhavya Sree, 2017). In this study, attributes like change in amount of work, control in work schedules, support from the office, team collaboration habits and assignments from superiors. As this pandemic has brought down changes in work life, these factors are considered to be more important.

\subsubsection{Wellbeing}

Wellbeing is seen in two main perspectives. As per hedonic perspective, well-being of an employee is the mental state of being happy. The eudaimonic perspective suggests that well-being is selfactualisation. (Dewe, 2012, Samanta et al., 2021). Well-being is more effective in an organisation where the employees feel the degree to connect with others in the workplace. (Alexis Keeman, 2017). Employee wellbeing is the primary factor in determining employee satisfaction. In this regard, attributes related to employee well-being such as time for family, time for fitness, refreshments at regular intervals and so on.

\subsubsection{Disturbance}

The distraction in work while working from home causes a lot of disturbances in the work and it may also lead to poor productivity. The absence of ergonomics at home may also bring down productivity as it affects the mental and physical condition of a human. People who work more than 11 hours per day suffer myocardial infarction. (Wong, K., Chan, 2019)

\subsubsection{Stressors}

The repercussions caused by Covid-19 has increased the stress level among employees. Stress occurs due to many factors. Working beyond working hours is commonly seen among the work from home employees. Though they are always with their family, they couldn't have quality time with their family members. This become a major stressor and found to have lot of influence in the work.

\section{REVIEW OF LITERATURE}

Audrone Nakroseine et.al (2019) studied various factors related to organisational outcome and individual factors of work from home. The study results from 128 remote workers stated that remote work results in reduced time for communicating with the workers [Audrone Nakrosiene, 2019]. Hernan Dario Cortes-Perez (2020) analysed the influence of lifestyle and cultural traits on remote work and found out that cultural traits have more influence on remote work than the lifestyle [Ellen Baker, 2019]. Tracey Crosbie (2004) studied the experience of work from home with 3 focus groups and found out that personality, skills and aspirations has more to do with the remote work [Crosbie, 2019]. Nicholas Bloom (2015) studied the effect of work from home 
among call centre employees in China. The study revealed that remote work is more suitable for call centre employees as it does not involve teamwork [Madhumitha Jaganmohan, 2019].

\subsection{Need for the study}

Covid 19 and the nationwide lockdown called for remote work in many industries. Though work from home is not a new one, the recent nation-wide work from home created hassle among the employees. Most of the employees are new to this work from home practice. Every tough situation brings out new possible ways of doing the old business. In this way, this lockdown showed the industries the benefit of remote work in terms of cost. On the other side, companies don't cannot compromise on worker productivity. It is always believed that the work environment plays a vital role in increasing productivity. This study is aimed at identifying the relationship between work style, lifestyle and job satisfaction of the employees.

\subsection{Objectives of the Study:}

To study employee's attitude towards remote work

To explore the factors influencing job satisfaction at remote work

To analyse the influence of wellbeing, disturbance factor and stressors on job satisfaction at remote work

\section{RESEARCH DESIGN}

\subsection{Research Design}

The Study is a descriptive research, trying to explain the changes in work style, personal life of the employees at work from home during the lockdown period due to covid-19.

\subsection{Sampling Technique}

Chennai is the one of the three largest software hubs in India. It also ranked among the top five cities affected by covid-19. Hence, it is decided to carry out this research with the respondents working in IT firms in and around Chennai. There are around 2,00,000 employees working in IT and ITES in Chennai [8]. The respondents are selected randomly from this population. Questionnaires are sent through electronic medium to 760 employees. Out of which 701 questionnaires were answered and considered for the study. The demographic profile, opinion towards change in work style and life style and opinion towards job satisfaction is measured using a structured and well-defined questionnaire. The questionnaire consists of six demographic questions such as age, gender, experience, marital status, number of children and monthly income. There is a categorical question for measuring the change in amount of work at work from home with three categories namely same amount of work, less amount of work and more amount of work. The second section of the questionnaire contains questions with Likert scale for measuring the opinion towards personal life(5attributes), work style(5 attributes) and job satisfaction(7 attributes) of the employees. These four variables are antecedent variables as the responses are expected to be the consequences of pandemic and lockdown. All the 17 questions used 5-point Likert scale with 1 representing Highly Disagree and 5 representing Highly Agree.

The research is carried out from the responses collected randomly selected samples of 701 employees working in various IT firms in and around Chennai. Cronbach alpha test is conducted to test the reliability of the questionnaire [7]. Latent variable correlation matrix is used to assess validity. KaiserMeyer-Oklin(KMO) measure is used to test the sample adequacy. Bartlett's test of sphericity is used to test the relatedness of the variables [2]. Total variance explained with the eigenvalues shows the variance explained by each factor. This helps to identify the factors which contribute more for the variance in the study. Communalities are measured to analyse the extent of correlation between all the items. The total variance explained helps to understand the study with reduced number of variables. The extraction sum of squared loadings explains the percentage of variance explained by each attribute. The rotated component matrix with the loadings helps to identify the principal component.

The impact of personal life, work style of the employees at work from home on job satisfaction is measured using multinomial logistic regression. Since both the dependent variable and independent variable under study uses a 5-point Likert scale, multinomial logistic regression is the suitable statistical tool to get the relationship between the variables. 


\subsection{Conceptual Model}

Figure No. 1. Conceptual Model

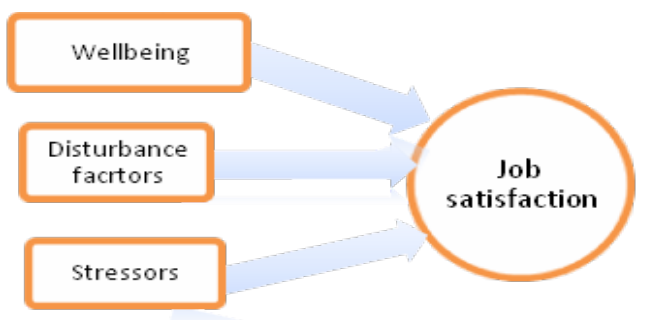

\section{DATA ANALYSIS AND INTERPRETATION}

Measuring the internal consistency of constructs

Table No.1. Reliability Statistics

\begin{tabular}{|l|l|l|}
\hline $\begin{array}{l}\text { Cronbach's } \\
\text { Alpha }\end{array}$ & $\begin{array}{l}\text { Cronbach's Alpha } \\
\text { Based on } \\
\text { Standardized Items }\end{array}$ & N of Items \\
\hline .880 & .884 & 17 \\
\hline
\end{tabular}

The internal consistency of the constructs is measured using the Cronbach's alpha test. There were 17 constructs used in this study with five-point Likert scale. The alpha value of 0.884 showed a high level of reliability for the scale used in this study. Demographic profile of respondents

Table No. 2: Demographic Profile of respondents

\begin{tabular}{|c|c|c|c|c|c|c|c|c|c|c|c|c|c|c|c|c|c|c|c|c|c|c|c|}
\hline & \multicolumn{2}{|c|}{ Gender } & \multicolumn{5}{|c|}{ Age } & \multicolumn{3}{|c|}{ Marital Status } & \multicolumn{3}{|c|}{$\begin{array}{c}\text { Number of } \\
\text { Children }\end{array}$} & \multicolumn{5}{|c|}{ Monthly Income } & \multicolumn{5}{|c|}{ Experience } \\
\hline & $\frac{0}{\pi}$ & 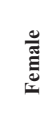 & $\mathscr{\tilde { v }}$ & ले & $\frac{O}{\frac{1}{m}}$ & $\frac{1}{7}$ & $\begin{array}{l}\text { 10 } \\
\text { : } \\
\text { \& }\end{array}$ & 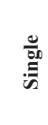 & $\frac{\overline{\mathrm{J}}}{\mathrm{E}}$ & 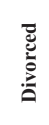 & 0 & - & $N$ & $\begin{array}{l}\text { ڤิ } \\
\text { : } \\
\text { v }\end{array}$ & 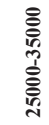 & 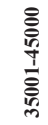 & 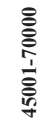 & 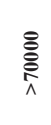 & $\begin{array}{l}\frac{n}{\tilde{E}} \\
\frac{\vec{V}}{\vec{v}}\end{array}$ & 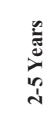 & 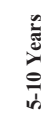 & 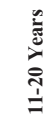 & $\frac{\tilde{N}}{\stackrel{\tilde{N}}{\tilde{N}}}$ \\
\hline $\begin{array}{l}\text { Frequenc } \\
\mathrm{y}\end{array}$ & $\begin{array}{l}47 \\
0 \\
\end{array}$ & $\begin{array}{l}23 \\
1 \\
\end{array}$ & $\begin{array}{l}23 \\
1 \\
\end{array}$ & 28 & $\begin{array}{l}23 \\
1 \\
\end{array}$ & $\begin{array}{l}17 \\
5 \\
\end{array}$ & 36 & $\begin{array}{l}22 \\
4 \\
\end{array}$ & $\begin{array}{l}47 \\
2 \\
\end{array}$ & 5 & $\begin{array}{l}41 \\
4 \\
\end{array}$ & $\begin{array}{l}19 \\
6 \\
\end{array}$ & 91 & 21 & $\begin{array}{l}22 \\
4 \\
\end{array}$ & $\begin{array}{l}14 \\
7 \\
\end{array}$ & 70 & $\begin{array}{l}23 \\
8 \\
\end{array}$ & 63 & $\begin{array}{l}16 \\
1 \\
\end{array}$ & $\begin{array}{l}10 \\
5 \\
\end{array}$ & $\begin{array}{l}19 \\
6 \\
\end{array}$ & $\begin{array}{l}17 \\
6 \\
\end{array}$ \\
\hline $\begin{array}{l}\text { Percentag } \\
\text { e }\end{array}$ & 67 & 33 & 33 & 4 & 33 & 25 & 5 & 32 & 67 & 1 & 59 & 28 & 13 & 3 & 32 & 21 & 10 & 34 & 9 & 23 & 15 & 28 & 25 \\
\hline
\end{tabular}

Table No. 2 provides the demographic profile of the respondents. $67 \%$ of the respondents are male and only $33 \%$ of the respondents are female. Majority of the respondents (58\%) belong to 31-50 age group. $33 \%$ of the respondents are less than 25 years of age. This shows that the study has included respondents from the different generations such as Xennial, millennial and Gen Z. Since there are so many differences prevailing among the psychology and attitude of all the above said generation, the coverage of all generations of employees in a fair proposition makes it more justifiable. $67 \%$ of the respondents from the study are married where as $32 \%$ of the respondents are single. Less than $1 \%$ of the surveyed respondents are divorcee and for the easy understanding purpose, it is marked as $1 \%$. Majority of the respondents (59\%) are having no children and in the remaining $41 \%, 28 \%$ of the respondents are with single children and $13 \%$ of the respondents are with two children. $34 \%$ of the respondents are drawing out more than 70,000 per month salary, $32 \%$ receive a salary between $25000-$ 35000 and $21 \%$ of respondents are drawing a salary between 35001 to 45000 . 53\% of respondents are having more than 10 years of experience and the remaining $47 \%$ of respondents are with less than 10 years of experience.

Table No.3: Descriptive statistics of the respondents

\begin{tabular}{|l|l|l|l|l|l|}
\hline & N & Minimum & Maximum & Mean & Std. Deviation \\
\hline Time for family & 701 & 1 & 5 & 3.70 & 1.419 \\
\hline Time for fitness & 701 & 1 & 5 & 2.60 & 1.372 \\
\hline Refreshment at regular intervals & 701 & 1 & 5 & 3.45 & 1.303 \\
\hline Working beyond working hours & 701 & 1 & 5 & 3.56 & 1.420 \\
\hline Time for sleep & 701 & 1 & 5 & 3.66 & 1.455 \\
\hline Stress at work & 701 & 1 & 5 & 3.38 & 1.392 \\
\hline Distraction & 701 & 1 & 5 & 3.13 & 1.325 \\
\hline Assignments from superior & 701 & 1 & 5 & 3.53 & 1.285 \\
\hline Change in amount of work & 701 & 1 & 5 & 3.41 & 1.436 \\
\hline
\end{tabular}




\begin{tabular}{|l|l|l|l|l|l|}
\hline Work beyond formal working hours & 701 & 1 & 5 & 2.97 & 1.470 \\
\hline More control in my work schedule & 701 & 1 & 5 & 3.64 & 1.188 \\
\hline Isolation at work & 701 & 1 & 5 & 3.42 & 1.353 \\
\hline Necessary support from office & 701 & 1 & 5 & 3.66 & 1.088 \\
\hline Team collaboration habits & 701 & 1 & 5 & 3.63 & 1.127 \\
\hline Mental health & 701 & 1 & 5 & 3.34 & 1.389 \\
\hline Physical health & 701 & 1 & 5 & 3.42 & 1.333 \\
\hline Company care for employees & 701 & 1 & 5 & 3.57 & 1.196 \\
\hline Valid N (list wise) & 701 & & & & \\
\hline
\end{tabular}

The study is conducted with 701 respondents. The mean, standard deviation, minimum and maximum is given in the descriptive statistics table. The mean and standard deviation is studied to understand the central tendency and variability for each variable under study. The mean of all the responses given on a five-point Likert scale tabulated above is around the mean value 3 which shows that the distribution of the responses is centred around. In the mean time, the standard deviations of the responses are between 1.088 and 1.470. This indicates that the measures show a very low dispersion. The mean value for time for fitness and work beyond formal working hours is below 3 with a low standard deviation which indicates most of the respondents are disagree that they spend more time for their fitness and they also work more beyond the normal working hours. Besides these two variables, all the other have a mean value around 3 and standard deviation below 2 which indicates that the data set under study is centred on the mean with a minimum variance.

Table No.4- Sampling adequacy - KMO and Bartlett's Test

\begin{tabular}{|l|l|l|}
\hline \multicolumn{2}{|l|}{$\begin{array}{l}\text { Kaiser-Meyer-Olkin Measure of } \\
\text { Sampling Adequacy. }\end{array}$} & .704 \\
\hline \multirow{2}{|c|}{$\begin{array}{l}\text { Bartlett's Test } \\
\text { of Sphericity }\end{array}$} & Approx. Chi-Square & 193.400 \\
\cline { 2 - 3 } & df & 3 \\
\cline { 2 - 3 } & Sig. & .000 \\
\hline
\end{tabular}

The sampling adequacy for the factor analysis is measured using the Kaiser Meyer Oklin test. The $\mathrm{KMO}$ value of 0.704 indicates high adequacy of the sample to be considered for factor analysis. The Bartlett's test of sphericity tests whether the correlation matrix is an identity matrix. [3]. The significance value of 0.000 which is less than 0.05 indicates that the variables are related to each other and suitable for factor analysis.

Table No. 5 Communalities

\begin{tabular}{|c|c|c|}
\hline & Initial & Extraction \\
\hline Time for family & 1.000 & .603 \\
\hline Time for fitness & 1.000 & .593 \\
\hline $\begin{array}{l}\text { Refreshment at regular } \\
\text { intervals }\end{array}$ & 1.000 & .622 \\
\hline Time for sleep & 1.000 & .537 \\
\hline Stress at work & 1.000 & .646 \\
\hline Distraction & 1.000 & .545 \\
\hline $\begin{array}{ll}\begin{array}{l}\text { Assignments } \\
\text { superior }\end{array} & \text { from } \\
\end{array}$ & 1.000 & .591 \\
\hline $\begin{array}{l}\text { Change in amount of } \\
\text { work }\end{array}$ & 1.000 & .622 \\
\hline $\begin{array}{l}\text { Work beyond formal } \\
\text { working hours }\end{array}$ & 1.000 & .668 \\
\hline $\begin{array}{l}\text { More control in my work } \\
\text { schedule }\end{array}$ & 1.000 & .727 \\
\hline Isolation at work & 1.000 & .607 \\
\hline $\begin{array}{l}\text { Necessary support from } \\
\text { office }\end{array}$ & 1.000 & .600 \\
\hline Team collaboration habits & 1.000 & .572 \\
\hline Mental health & 1.000 & .570 \\
\hline Physical health & 1.000 & .680 \\
\hline $\begin{array}{lll}\text { Company care for } \\
\text { employees }\end{array}$ & 1.000 & .531 \\
\hline
\end{tabular}

The percentage of variance of each variable is given by the communalities. The communality values of all the sixteen constructs under study are greater than 0.5 indicates that all the variables put together will hold good for factor analysis.

Table No.6 - Total Variance Explained

\begin{tabular}{|l|c|l|l|l|l|l|l|l|l|}
\hline Component & \multicolumn{3}{|c|}{ Initial Eigen values } & \multicolumn{2}{c|}{$\begin{array}{c}\text { Extraction Sums of Squared } \\
\text { Loadings }\end{array}$} & \multicolumn{3}{c|}{$\begin{array}{c}\text { Rotation Sums of Squared } \\
\text { Loadings }\end{array}$} \\
\hline & Total & $\begin{array}{c}\text { \% of } \\
\text { Variance }\end{array}$ & $\begin{array}{c}\text { Cumulati } \\
\text { ve \% }\end{array}$ & Total & $\begin{array}{c}\text { \% of } \\
\text { Variance }\end{array}$ & $\begin{array}{c}\text { Cumulati } \\
\text { ve \% }\end{array}$ & $\begin{array}{c}\text { Total } \\
\% \text { of } \\
\text { Variance }\end{array}$ & $\begin{array}{c}\text { Cumulati } \\
\text { ve \% }\end{array}$ \\
\hline 1 & 6.094 & 38.085 & 38.085 & 6.094 & 38.085 & 38.085 & 2.932 & 18.327 & 18.327 \\
\hline 2 & 1.441 & 9.003 & 47.088 & 1.441 & 9.003 & 47.088 & 2.613 & 16.329 & 34.656 \\
\hline 3 & 1.166 & 7.290 & 54.378 & 1.166 & 7.290 & 54.378 & 2.532 & 15.823 & 50.479 \\
\hline 4 & 1.015 & 6.345 & 60.723 & 1.015 & 6.345 & 60.723 & 1.639 & 10.245 & 60.723 \\
\hline
\end{tabular}




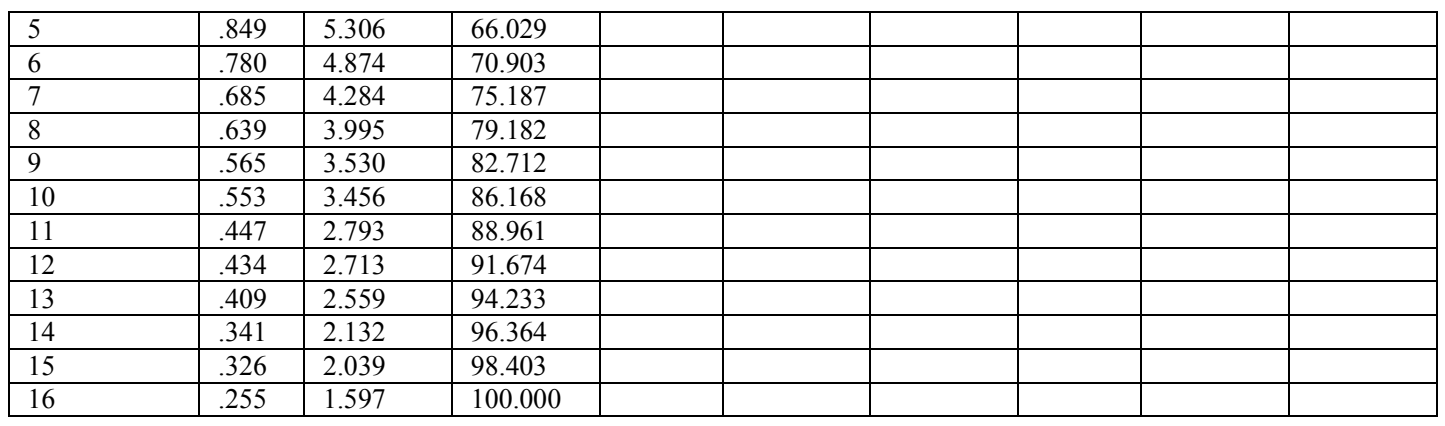

The Eigen values in Table no: 6 are the variances of the principal components.

Table No. 6 consists of the factor loadings given by the Principal Component analysis. The table shows that the variance explained is $61 \%$ and it has extracted 4 components from the seventeen components used in the study. This shows that the seventeen variables can be grouped into 4 for the better understanding of the study. The grouping of variables will be made after analysing the relationship the relationship between the variables. This can be done using the factor loadings given under rotated component matrix.

Table No.7 Rotated Component Matrix

\begin{tabular}{|l|l|l|l|l|}
\hline & \multicolumn{4}{|l}{ Component } \\
\hline & $\mathbf{1}$ & $\mathbf{2}$ & $\mathbf{3}$ & $\mathbf{4}$ \\
\hline Time for family & .104 & .139 & .718 & .241 \\
\hline Time for fitness & -.005 & .246 & .726 & .073 \\
\hline $\begin{array}{l}\text { Refreshment at } \\
\text { regular } \\
\text { intervals }\end{array}$ & .274 & .151 & .714 & .121 \\
\hline Time for sleep & .429 & .162 & .563 & .096 \\
\hline Stress at work & .145 & .455 & .339 & .550 \\
\hline Distraction & .170 & .690 & .199 & .016 \\
\hline $\begin{array}{l}\text { Assignments } \\
\text { from superior }\end{array}$ & .573 & .296 & .319 & -.272 \\
\hline $\begin{array}{l}\text { Change in } \\
\text { amount of work }\end{array}$ & .731 & .190 & .217 & -.067 \\
\hline $\begin{array}{l}\text { Work beyond } \\
\text { formal working } \\
\text { hours }\end{array}$ & .098 & -.106 & .336 & .731 \\
\hline $\begin{array}{l}\text { More control in } \\
\text { my work } \\
\text { schedule }\end{array}$ & .682 & .201 & -.044 & .468 \\
\hline $\begin{array}{l}\text { Isolation at } \\
\text { work }\end{array}$ & .080 & .576 & .044 & .516 \\
\hline $\begin{array}{l}\text { Necessary } \\
\text { support from } \\
\text { office }\end{array}$ & .699 & .213 & .007 & .255 \\
\hline $\begin{array}{l}\text { Team } \\
\text { collaboration } \\
\text { habits }\end{array}$ & .650 & .242 & .277 & .121 \\
\hline
\end{tabular}

\begin{tabular}{|l|l|l|l|l|}
\hline Mental health & .408 & .523 & .244 & .266 \\
\hline Physical health & .312 & .699 & .307 & .000 \\
\hline $\begin{array}{l}\text { Company care } \\
\text { for employees }\end{array}$ & .306 & .653 & .108 & -.007 \\
\hline
\end{tabular}

Table 7 gives the factor loadings based on Principal component analysis using Varimax with Kaiser Normalization. There are five variables showing high correlation which is more than 0.5 with the factor 1 . So the factor 1 is formed with the variables such as change in amount of work, more control in my work schedule, necessary support from my office, team collaboration habits, assignments from superiors. The factor 1 is then assigned a name, Job Satisfaction. The second factor comprises of the variables distraction, isolation, mental health and physical health. This is given the label as "Disturbance factor". Factor 3 comprises of four factors namely time for family, time for fitness, refreshment at regular intervals and time for sleep. This is labelled as Wellbeing boosters. Factor 4 is named as stressors as it has the two variables stress at work and working beyond normal working hours. Finally, from the exploratory factor analysis there were four factors identified. Out of the four factors, Job satisfaction, a factor with five variables is considered as the dependent variable of the study and the other variables such as wellbeing factors, disturbance factors and stressors are considered as independent variable.

The sixteen constructs used in this study is measured on a Likert scale. In this case, it is not possible to use linear regression which holds good only for continuous scale. Ordinal regression is the right tool to use for finding the intensity of relationship between two or more variables with ordinal scale. The regression model is constructed between the dependent variable job satisfaction and the independent variables wellbeing, disturbance and stressors. 
Table 8: Model Fitting Information

\begin{tabular}{|l|l|l|l|l|}
\hline Model & $\begin{array}{l}\mathbf{- 2} \\
\text { Likelihood }\end{array}$ & $\begin{array}{l}\text { Chi- } \\
\text { Square }\end{array}$ & df & Sig. \\
\hline $\begin{array}{l}\text { Intercept } \\
\text { Only }\end{array}$ & 1081.071 & & & \\
\hline Final & 899.345 & 181.726 & 39 & .000 \\
\hline
\end{tabular}

The chi square value from the model fitting information in the Table No.8 compares the final model and the baseline model which uses only the intercept. The p-value (0.000) which is less than 0.05 indicates that the model is statistically significant. Hence, it is observed that this model offers improved forecasts than the base model which uses only the marginal probabilities.

Table 9: Goodness-of-Fit

\begin{tabular}{|l|l|l|l|}
\hline & $\begin{array}{l}\text { Chi- } \\
\text { Square }\end{array}$ & df & Sig. \\
\hline Pearson & 4570.150 & 2805 & .053 \\
\hline Deviance & 889.876 & 2805 & 1.000 \\
\hline
\end{tabular}

Link function: Logit.

Table No. 9 is used to test that whether the data used is reliable with the fitted model. The p-value
(0.053) shows that the model fits well for the study. After checking the model fitness, we should see the Pseudo $\mathrm{R}^{2}$.

Table 10- Pseudo R-Square

\begin{tabular}{|l|l|}
\hline Cox and Snell & .597 \\
\hline Nagelkerke & .599 \\
\hline McFadden & .166 \\
\hline
\end{tabular}

Link function: Logit.

The pseudo R2 value explains the proportion of variance in dependent variable explained by the independent variables. Table No.10 shows that $60 \%$ of the variance in Job satisfaction can be explained by the independent variables well being, disturbance factor and stressors.

The observed significance levels for all the variables except the mental health and assignment from superior are less than 0.05 . This means that the variables job satisfaction except the assignment given by superior is affected by the variables well being, disturbance factors and stressors. Mental health in disturbance factor is not related to job satisfaction as it has a high significant value.

Table No.11 Parameter Estimates

\begin{tabular}{|c|c|c|c|c|c|c|c|c|}
\hline & \multirow[t]{2}{*}{ Estimate } & \multirow[t]{2}{*}{ Std. Error } & \multirow[t]{2}{*}{ Wald } & \multirow[t]{2}{*}{ df } & \multirow[t]{2}{*}{ Sig. } & \multicolumn{2}{|l|}{$\begin{array}{l}95 \% \\
\text { Confidence } \\
\text { Interval } \\
\end{array}$} & \\
\hline & & & & & & Lower Bound & Upper Bound & \\
\hline \multirow{6}{*}{ Threshold } & {$[$ Jobsatisfaction $=1]$} & -9.842 & .954 & 106.529 & 1 & .000 & -11.711 & -7.973 \\
\hline & {$[$ Jobsatisfaction $=2]$} & -7.486 & .792 & 89.264 & 1 & .000 & -9.039 & -5.933 \\
\hline & {$[$ Jobsatisfaction $=2]$} & -7.119 & .779 & 83.592 & 1 & .000 & -8.645 & -5.593 \\
\hline & {$[$ Jobsatisfaction $=3]$} & -6.935 & .773 & 80.575 & 1 & .000 & -8.449 & -5.421 \\
\hline & {$[$ Jobsatisfaction $=4]$} & -3.995 & .710 & 31.650 & 1 & .000 & -5.387 & -2.603 \\
\hline & {$[$ Jobsatisfaction $=5]$} & .514 & .654 & .617 & 1 & .042 & -.768 & 1.795 \\
\hline \multirow{15}{*}{ Location } & [Wellbeing=1] & -2.564 & 1.003 & 6.533 & 1 & .011 & -4.530 & -.598 \\
\hline & [Wellbeing=2] & -1.464 & .996 & 2.162 & 1 & .041 & -3.416 & .488 \\
\hline & {$[$ Wellbeing=3] } & -.371 & .795 & .218 & 1 & .641 & -1.929 & 1.187 \\
\hline & [Wellbeing=3] & -.829 & .734 & 1.277 & 1 & .048 & -2.267 & .609 \\
\hline & {$[$ Wellbeing=4] } & .514 & .740 & .482 & 1 & .047 & -.936 & 1.964 \\
\hline & {$[$ Wellbeing $=5]$} & 1.134 & .838 & 1.832 & 1 & .016 & -.508 & 2.776 \\
\hline & [Wellbeing=5] & $0^{\mathrm{a}}$ & . & . & 0 & . & . & . \\
\hline & {$[$ Stress $=1]$} & -1.100 & .693 & 2.515 & 1 & .013 & -2.459 & .259 \\
\hline & {$[$ Stress $=2]$} & -.550 & .496 & 1.231 & 1 & .007 & -1.522 & .422 \\
\hline & {$[$ Stress $=3]$} & $0^{\mathrm{a}}$ & . & . & 0 & . & . & . \\
\hline & {$[$ Disturbance $=1]$} & -5.166 & 1.162 & 19.752 & 1 & .000 & -7.444 & -2.888 \\
\hline & {$[$ Disturbance $=2]$} & -6.234 & .916 & 46.358 & 1 & .000 & -8.029 & -4.440 \\
\hline & {$[$ Disturbance $=3]$} & -1.223 & .781 & 2.453 & 1 & .017 & -2.753 & .307 \\
\hline & {$[$ Disturbance $=4]$} & -2.616 & .838 & 9.747 & 1 & .002 & -4.258 & -.974 \\
\hline & {$[$ Disturbance $=4]$} & $0^{\mathrm{a}}$ & . & . & 0 & . & . & . \\
\hline
\end{tabular}

Link function: Logit.

a. This parameter is set to zero because it is redundant. 
Table 12: Test of Parallel Lines

\begin{tabular}{|l|l|l|l|l|}
\hline Model & $\begin{array}{l}\text {-2 Log } \\
\text { Likelihood }\end{array}$ & $\begin{array}{l}\text { Chi- } \\
\text { Square }\end{array}$ & df & Sig. \\
\hline $\begin{array}{l}\text { Null } \\
\text { Hypothesis }\end{array}$ & 899.345 & & & \\
\hline General & $.000^{\mathrm{b}}$ & 899.345 & 663 & .000 \\
\hline
\end{tabular}

The null hypothesis states that the location parameters (slope coefficients) are the same across response categories.

a. Link function: Logit.

b. The log-likelihood value is practically zero. There may be a complete separation in the data. The maximum likelihood estimates do not exist.

From the significance value obtained from test of parallel lines, it is evident that the dependent variables well being, disturbance factors and stressors are the same across the dependent variable job satisfaction.

\section{CONCLUSIONS}

The pandemic covid-19 has created a greater impact on all aspects of human life and economy. The remote work option adopted by many companies instantaneously created havoc among employees. This remote work has its consequence on the well being, distraction factors and stress factors of the employees which in turn affect job satisfaction. This study analysed the influence of change in well being of the employees, disturbance factors during work at home and stressors due to remote work on job satisfaction. The various constructs are grouped to four using the factor loadings from principal component analysis. The regression analysis showed that well being, disturbance factors and stressors are equally influencing the job satisfaction level of employees.

\section{REFERENCES}

[1] Audrone Nakrosiene, et al. "Working from home: Characteristics and outcomes of telework." International Journal of Manpower, vol. 7.

[2] Brett Williams er al., "Exploratory factor analysis: A five-step guide for novices." Australian Journal of Paramedicine 8(3), 2010.

[3] "Covid-19: companies pull out all stops to work from home." Economic times [chennai], 21 march 2020
[4] Donna Harrington. confirmatory factor analysis. oxford university press, 2009.

[5] Ellen Baker, and Gayl. "Satisfaction and perceived productivity when professionals work from home." Research and practice in Human Resource Management, vol. 1, no. 1, 2019, 3762.

[6] Hernan Dario. "Influence of lifestyle and cultural traits on the willingness to telework: A Case study in the Aburra valley." 2020, www.who.int/india/emergencies/novelcoronavirus-2019.

[7] India ramps up effort to contain the spread of novel coronavirus, World Health Organisation

[8] Joseph A.Gliem, and Rosemary R.Gliem,. "Calculating, interpreting and reporting Cronbach's Alpha Reliability Coefficient for Likert - Type scales,." Midwest Research to Practice conference in Adult, continuing and community education, 2003, pp. 8-10.

[9] Madhumitha Jaganmohan. "IT industry in India - Statistics and facts.” Statista, , 2020

[10] Nicholas Bloom. "Does working from home work? Evidence from a Chinese experiment." Quarterly Journal of economics, Stanford University., 2015.

[11] Nicholas Bloom. "To raise productivity, let more employees work from home." Harvard Business Review, January-February 2014.

[12] Pamela S.Tolber, and Tal Simons. "The impact of working at home on career outcomes of Professional employees,." CAHRS Working Paper Series, 1994. https://digitalcommons.ilr.cornell.edu/cahrswp/ 229.

[13] Prithwiraj(Raj) Choudhury. "Is it Time to let employees work from anwhere?" Harvard Business Review, August 2019.

[14] "Rolling updates on corona virus,." Rolling updates on corona virus, world health organisations, https://www.who.int/emergencies.

[15] Tracey Crosbie. "Work Life Balance and Working from home." Social policy and society, vol. 3, no. 3, 2004, pp. 223-233.

[16] Tracey Crosbie, and Jeanne Moore. Work life Balance and working from home, Social Policy 
\& society. vol. 3, Cambridge University Press. 3 vols.

[17] Dewe, P., and Cooper, C. (2012). Well-being and Work: Towards a Balanced Agenda. Basingstoke: Palgrave MacMillan.

[18] Alexis Keeman, Katharina Naswall, Sann Malinen, Joana Kuntz, Employee Wellbeing: Evaluating a Wellbeing Intervention in Two Settings, vol 8, ISSN=1664-1078, pp: 505. DOI $=10.3389 /$ fpsyg. 2017.00505

[19] SR Samanta, B Rautaray, DK Swain, Ensuring better output in library services through work life balance: a study of librarians' opinion, Global Knowledge, Memory and Communication 70 (6/7), (2021) 504-517

[20] Wong, K., Chan, A., \& Ngan, S. C. (2019). The Effect of Long Working Hours and Overtime on Occupational Health: A Meta-Analysis of Evidence from 1998 to 2018. International journal of environmental research and public health, 16(12), 2102. https://doi.org/10.3390/ijerph16122102 